\title{
MANUSIA TORAJA DALAM KHAS BUDAYA YANG UNIK DAN BERNILAI TINGGI
}

\author{
SEPTIAN \\ Institut Agama Kristen Negeri Toraja \\ Septiansirrang@gmail.com
}

Abstrak :

Talking about a unique culture, all regions have a culture that stands out in particular, the culture of the Toraja people which is very thick until it is know in foreign countries and even in the eyes of the world. From this distinctive culture, Toraja also does not underestimate education, Toraja riset for the future, children, and grandchiidren of the nation's next generation who are not less competitive than other regions. Toraja human culture has unique values that are very valuable, antique and not shared by other cultures. Such a harmonious leadership system which upholds customs or caste/ Tana'. And Toraja people have a high social spririt.

Keyword :

Thick culture, leadership,education social, Toraja people.

Abstrak :

Berbicara tentang budaya yang khas maka semua daerah memiliki budaya yang menonjol secara khusus budaya orang Toraja yang sangat kental sampai dikenal sampai kemanca Negara dan bahkan dunia sekaligus. Dari budaya ini Toraja juga tidak terlepas dari perhatian bagi pendidikan untuk masa depan anak dan cucu generasi penerus bangsa yang takala daya saing dari daerah lain. Kebudayaan manusia Toraja sangat memiliki nilai khasnya yang sangat antik, dan tidak dimiliki oleh budaya lain dalam artian bahwa berbeda daripada yang lain. Sistem kepemimpinan yang begitu harmoni yang dimana menjunjung tiggi keadatan atau kasta/ Tana' dan manusia Toraja memiliki iwa sosial yang tinggi.

Kata kunci :

Kentalnya budaya, kepemimpinan, pendidikan, sosial, manusia Toraja

\section{PENDAHULUAN}

Manusia Toraja hidup dalam komunitas yang sangat - sangat kental dengan budaya yang unik dan bernilai tinggi. Budayanya yang kental membuat Toraja dikenal oleh dunia dan budaya yang telah tertata dengan baik sejak dari nenek moyang mereka itu yang menjadi nilai ples bagi manusia Toraja karena kearifan lokal mereka masih terjaga hingga pada saat ini.

Konsep kepemimpinan yang dijunjung tinggi oleh manusia Toraja sangat lah berpengaruh pada suatu kasta atau Tana' mereka yang memiliki Tana' tertinggi itulah yang menjadi pemimpin golongan pada kasta atau Tana' golongan bawa. Dalam menjalankan kepemimpinan ini manusia Toraja memiliki aturanaturan atau falsafa-falsa hidup dimana semua di atur dalam suatu tatatan keadatan namun yang unik nya bahwa aturan yang dibuat bukan dalam bentuk tulisan namun bentuknya adalah lisan. Di Toraja adanamanya Tongkonan/ rumah adat. Kendati demikian tidak semua tongkonan dapat menjadi pemimpin atau penguasa, namun suatu tongkonan dapat hadir karena adanya suatu kepemimpinan. 
Toraja juga takkalah memperhatikan pendidikan bagi generasi mereka terbukti bahwa banyak darah toraja yang berhasil dikanca dunia nasional bahkan internasional sekalipun. Pendidikan sejatinya bukan satu-satunya diperoleh melalui sesuatu pendekatan formal namun faktanya manusia Toraja lebih dominan diperoleh ( dipelajari) justru melalui budaya, dan secara kongrit lebih banyak melalui keteladanan dan relasi atau hubungan sosial. Manuasia Toraja bukan mereka hanya memperbanyak teori namun mereka banyak teori dan lebih cenderung kepraktek itulah yang tidak dimiliki oleh orang lain selain orang Toraja yang mampu menyimbangi Teori dan praktek dalam tatanan pendidikan mereka.

Budaya mereka merupakan hasil oleh rasa dan karsa menjadi daya tarik bagi berbagai pihak dari luar baik melakukan penelitian, dokumentasi untuk tujuan publikasi. Kehidupan dan budaya manusia Toraja tersebut mengambarkan kualitas berpikir dan kualitas hidup mereka yang tidak terpisahkan dari identitas mereka dan kearifan lokal budaya dan daerah mereka. Manakalah masyarakatnya hidup saling-tolong menolong atau gotong royong dalam artian bahwa satu susah semua susah satu senang semua ikut senang itulah keunggulan mereka

\section{TUJUAN DAN MANFAAT}

Dalam memebuat tulisan ini ada tujuan yang akan dicapai. Yaitu dimana banyak hal yang masih ingin diceritakan mengenai manusia Toraja dan khas budaya nya yang masih sangat relevan kental . manusia Toraja adalah sekolompok manusia yang memiliki keunikan tersendri dari sinilah akan dikaji bagimana budaya luhur yang masih tersembunyi dalam diri dan leluhur manusia Toraja dalam gelaran daerah "Lepongan Bulan Tanah Matari Allo" .Manfaatnya adalah supaya semua secara khusus manusia yang berdarah Toraja mengetahui asal-usul mereka, mengetahui betapa berharganya daerah mereka yang kaya akan budaya leluhur mereka yang masih sangat kental dengan budaya leluhur yang kian turun temurun.

\section{PEMBAHASAN}

Tana' dalam kamus Toraja-indonesi dijelskan bahwa tana' sama dengan pato'. Yaitu suatu ketentuan yang telah ditentukan atau telah menjadi tolak ukur untuk dijadikan sebagai dasar suatu peraturan ditetapkan sebagai asas sesuatu hukum atau aturan yang dibuat dalam satu kesatuan didalam sebuah wadah untuk menjadi acuan dan pedoman.

Pengertian tersebut diatas membuka ruang pemahaman kita tentang Tana' sama dengan lapisan sosial yang melembagai atau memimpin suatu kelompok. Dengan demikian dapat ditarik satu kesimpulan bahwa Tana' adalah suatu norma yang dijadikan patokan, struktural oleh manusia Toraja yang telah diakui sejak dari leluhur mereka, oleh karena kasta mereka yang berbeda-beda sehingga lahirlah suatu pemimpin dalam wilayah keadatan mereka. ${ }^{1}$

Realita sosial dan fenomena empirik yang terlihat secara langsung sehubungan dengan budaya orang Toraja adalah simbol sosial kemasyarakatan terkecil sampai pada kemasyarakatan terbesar yakni rumah atau tongkonan. Rumah dalam arti sempit, yaitu tongkonan yang merupakan kontruksi budaya yang didirikan oleh nenek moyang mereka sejak duluh dan hingga pada saat ini masih banyak yang bisa kita jumpai. Manusia Toraja ( dalam pengertian primitif), sejarah dilihat sebagai pengungkapan ontologi mistis yang terus-menerus mengulangi tindakan primodial secara sadar melalui pemaknaan isyarat maupun paradikma. Manusia Toraja memiliki raealita terhadap komunitasnya sangatlah kuat dan saling

\footnotetext{
${ }^{1}$ Rannu sanderan, “STRATIFIKASI SOSIAL kepemimpinan Tradisional dalam Dinamika Modern” , 2 \& 4
} 
mendukung. ${ }^{2}$ Mereka kata orang bahwa terlahir dengan kekayaan akan budaya yang sangat indah dan berharaga itu satu kelebihan manusia Toraja memiliki tongkonan, dari tongkonan itulah mereka bisa mengenal satu sama lain meskipun banyak yang berjauhan.

Lingkunagan masyarakat yang baik ( dalam konteks dominan) memegang teguh nilai-nilai dan normanorma perilaku yang baik, sejatinya itu menjadi penyokong kehidupan manusia Toraja karena mereka mengikuti dan mendengarkan apa kata pemimpinya atau kasta yang memimpin. Perilaku manusia lebih banyak berfungsi karena dibentuk oleh pengamatan dan dipengaruhi oleh proses kehidupan pada zaman nenek moyang mereka hingga saat ini. ${ }^{3}$ Manusia Toraja sangat menghargai leluhur mereka ditandai dengan acara yang mereka lakukan lebih banyak cenderung mewa dan mahal pada acara kematia ( Rambu Solo') dari pada pengorbanan mereka pada acara pernikahan (Rambu Tuka') mereka juga tidak tanggung-tangun mebuat tempat menyimpan jenazah kerabat mereka yang lebih dulu berpulang kepada sang pemilik kehidupan ( Puang Matua).

Budaya modernisme dan globalisasi membawa berbagai kemudahan bagi umat manusia. Secara perlahan namun pasti manusia didoktin oleh lingkungan untuk menjadi pemburu kesenangan yang tidak pernah terpuskan. Manusia Toraja seiring berjalan nya waktu kebudayaan mereka juga perlahan-lahan menurun namun ketika dipahami dan disadari bahwa kultur budaya memiliki peran dalam kehidupan sosial mereka. ${ }^{4}$ Kendatipun tongkonan dipahami persial dan dangkal yakni sekedar bangunan rumah tradisioanal saja, namun pasang surut berbudaya mereka ini menarik untuk dicari tahu, hingga bisa membentuk satu etnis budaya lokal yang perennial. Tanpa pengajaran institusiol formal, namun secara dinamis Manusia Toraja bisa bertumbuh dalam karakter luhur, sanggup beradaptasi dan dan bertahan ditengah pengaruh identitas budaya baru. ${ }^{5}$

Kemungkinan setiap orang memimpikan adanya suatu masayrakat atau komunitas yang inklusif, yang hidup dalam persaudaraan yang baik dan benar, dalam harmoni; dimana setiap orang menghargai kesetaraan dan perakuan adil. Masyarakat yang demikian mestinya bukan hanya suatu mimpi belaka, melaikan suatu mimpi yang seyogianya menjadi kenyataan. ${ }^{6}$

\section{KESIMPULAN DAN SARAN}

Dalam tulisan ini dapat disimpulkan bahwah manusia Toraja dengan adat kebudayaanya yang khas membuat mereka dikenal diberbagi daerah dalam negeri maupun luar negeri. Mereka sungguh luar biasa

\footnotetext{
${ }^{2}$ Rannu sanderan, " Heuristika dalam Pendidikan Karakter Manusia Toraja Tradisional” , Jurnal Teologi dan Pendidikan Kristen Kontekstual. 308-309

${ }^{3}$ Rannu sanderan, " menemukenali Kunci Pendidikan Iman bagi Anak dalam keluarga dan Pembelajaran Agama Kristen di sekolah", 2

${ }^{4}$ Rannu sanderan, "Kontribusi disiplin Diri bagi Pengembangan Pendidikan Kristen" 2

${ }^{5}$ Rannu sanderan, "Heuristika dalam Pendidikan Karakter Manusia Toraja Tradisional” , jurnal Teologi dan Pendidikan Kristen Kontekstual" 309

${ }^{6}$ Rannu sanderan, “ jabatan Gerejawi dan Peran Perempuan Dalam Pelayanan Gereja” 2
} 
tatanan dalam kasta dan tongkonan mereka mebuat mereka semakin eksis dikacamata dunia. Adapun saran untuk kita suapaya tetap berkarya demi daerah kita khususnya Toraja apapun bentuk dan caranya yang penting bersifat membangun. Kritik dan saran yang membangun sangat dibutuhkan oleh penulis.

\section{DAFTAR PUSTAKA}

Sanderaan rannu, “STRATIFIKASI SOSIAL kepemimpinan tradisonal dalam dinamika modern” $2 \& 4$.

Sanderan rannu, “ Heuristika dalam Pendidikan Karakter Manusia Toraja Tradisional”. Jurnal Teologi dan pendidikan Kristen Kontekstual.308-309

Sanderan rannu, " menemukenali Kunci pendidikan Iman Anak dalam Keluarga dan Pembelajaran Agama Kristen di Sekolah” 2

Sanderan rannu, “Kontribusi displin Diri bagi pengembangan Pendidikan Kristen” 2

Sanderan rannu, "Heuristika dalam Pendidikan Karakter Manusia Toraja Tradisonal” , Jurnal Teologi dan pendidikan Kristen Kontekstual" 309

Sanderan rannu, “Jabatan Gerejawi dan Peran Perempuan Dalam Pelayanan Geraja” 2 